\title{
Chemical and biological studies on spreadable processed cheese made using flaxseed oil as butter substitute
}

\author{
S. O. Ahmed ${ }^{1}$, R. A. Awad ${ }^{2}$, M. A. Ali ${ }^{1}$ and M. R. M. Rashid ${ }^{1, *}$ \\ ${ }^{1}$ Dairy Science Department, Faculty of Agriculture, Al-Azhar University, Cairo, Egypt \\ ${ }^{2}$ Food Science Department, Faculty of Agriculture, Ain shams University, Shoubra El-Khaima, Cairo, \\ Egypt
}

*Corresponding author E-mail: Mohamedrashed_5@azhar.edu.eg (M. Rashid).

\begin{abstract}
Foods are not intended to only satisfy hunger and to provide basic nutritional requirements but also to prevent nutrition-related diseases and to improve physical and mental well-being of the consumers. This research studied the improve of nutritional and potential therapeutic value of processed cheese using flaxseed oil because of its high nutritional and health value. Full-fat spreadable processed cheese made by butter substitution levels of nil (control), 25, 50, 75 and 100\% with flaxseed oil. Sensory evaluation, chemical, rheological, and biological properties were evaluated to study the effect of addition of flaxseed oil on processed cheese properties. The results of sensory evaluation of samples demonstrated that the best treatment of analogue cheese was the cheese with $25 \%$ of flaxseed oil. As the processed cheese contained flaxseed oil, the total unsaturated increased. The incorporation of the flaxseed oil into the processed cheese caused a high increment in Linoleic, Linolenic and Arachidic acids. The cheese samples with 25 and $50 \%$ of flaxseed oil were the nearest to the control sample towards rheological properties. At the end of the experiment ( 28 days), rats were fed on processed cheese of flaxseed oil gained higher body weights than those fed only base diet. The total serum cholesterol was lowered in the rats group fed on processed cheese containing $25 \%$ flaxseed oil and processed cheese containing $75 \%$ flaxseed oil. From these results, it could be recommended flaxseed oil as butter partial substitute in processed cheese manufacture up to $75 \%$ to achieve the health benefits propose with good sensory acceptability and reasonable rheological properties.
\end{abstract}

Keywords: Rheological properties; Fatty acids composition; Blood serum profile.

\section{INTRODUCTION}

In the relationship between diet, health and well-being, functional foods play an outstanding role. Many definitions exist worldwide for functional foods, but there is no official or commonly accepted definition (Kalra, 2003). The relationship between milk fat intake and health impact is complex (German et al., 2009) and much has been written on the association between dairy and cardiovascular disease (CVD) risk factors. Vegetable oils exert advantage over milk fat in a way that they make it possible to balance the content of saturated and unsaturated fats in the composition. Flaxseed oil is naturally low in saturated fat and provides a moderate amount of monounsaturated fat. Roughly $73 \%$ of fatty acids in flaxseed oil are polyunsaturated. Flaxseed oil is particularly rich in $\alpha$ linolenic acid (ALA), an omega-3 fatty acid; it contains a lower amount of linoleic acid (LA), an omega-6 fatty acid. Because of its high (ALA) contain, flaxseed oil has an omega-6/omega-3 fatty acid ratio of 1:3 (Bhatty, 1995). Processed cheese is a very important dairy product that is produced and handled easily without the need for special conditions because of its high conservation capacity; it also cast a very popular product, especially for children owing to likeable savor and distinctive texture. Processed cheese differs from natural cheese in the fact that processed cheese is not made directly from milk. However, the main ingredient of processed cheese is natural cheese. Processed cheese is produced by blending natural cheese of different ages and degrees of maturity in the presence of emulsifying salts and other dairy and nondairy ingredients followed by heating and continuous mixing to form a homogeneous product with an extended shelf life (Meyer, 1973; Thomas, 1973; Guinee et al., 2004).

The main target of the present investigation is to produce healthy processed cheese by partial replacement of 
the milk fat with flaxseed oil rich in its content of unsaturated fatty acids, especially omega-3, to benefit from the healthy effect of these acids to reduce the harmful cholesterol and reduce the incidence of cardiovascular disease. Thus, the following points were including in the present study: (a) Study the effect of partial replacement of milk fat by $25 \%, 50 \%, 75 \%$ and $100 \%$ flaxseed oil in processed cheese on sensory, physical and chemical properties. (b) Evaluation the impact of feeding rates on produced processed cheese on serum lipids of rats.

\section{MATERIALS AND METHODS}

\section{Materials}

Ras cheese ( 1 month old) was obtained from Mariam Co., Giza, Egypt. Butter was obtained from Sakr Group Co., Egypt. Fresh cow's milk (3\% fat) was obtained from the farm of Faculty of Agriculture Cairo University, Giza, Egypt. Fresh skimmed milk was gained by the mechanical separation of fresh cow's milk. Skimmed milk powder. Joha S9S emulsifying salt was obtained from the BK Giulini Chemie $\mathrm{GmbH}$, Landenberg, Germany. Cold pressed flaxseed oil was obtained from the Extract and Press Oil Unit, National Research Center, Dokki, Giza, Egypt. Twenty mature male Albino rates, with mean body weights of $125 \pm 5 \mathrm{~g}$. were obtained from Animal house, National Research Center, Dokki, Cairo, Egypt. The chemical composition of rat's basal diet was as follows: raw protein, $23 \%$; raw fat, $3.40 \%$; fibers, $3.60 \%$, starch, $62 \%$ and ash $8 \%$. Table (1) showed the chemical composition of the ingredients used in manufacture of processed cheese analogue.

Table 1. Composition of raw materials used in the manufacture of processed cheese spreads.

\begin{tabular}{ccccc} 
& \multicolumn{4}{c}{ Ingredient } \\
\cline { 2 - 5 } Component (\%) & Ras cheese & Butter & $\begin{array}{c}\text { Skimmed } \\
\text { milk } \\
\text { powder }\end{array}$ & $\begin{array}{c}\text { Skimmed } \\
\text { milk curd }\end{array}$ \\
\hline Total solids & 57.50 & 84.00 & 96.00 & 32.00 \\
Fat & 25.00 & 81.99 & 1.50 & 0.00 \\
Protein (TN× 6.38) & 22.26 & ND & 37.13 & 12.37 \\
Ash & 5.76 & ND & 7.89 & 2.63 \\
\hline
\end{tabular}

TN: Total nitrogen, ND: Not Detected.

\section{Experimental procedures}

\section{Manufacture of processed cheese analogue}

Processed cheese based on 55-58 \% moisture and $45-50 \%$ fat/dry matter (F/DM) was manufactured as described by Savello et al. (1989) with some modifications as follow: Ras cheese and skimmed milk curd were milled and mixed with water and emulsifying salt in addition to butter substituted with nil (control), 25, 50,75 or $100 \%$ flaxseed oil as butter replacer. All blends recipes are in Table (2). The blends were placed into the processing bath type kettle of $5 \mathrm{~kg}$ capacity, a pilot machine at faculty of agriculture, Ain shams University, Cairo, Egypt. The cheese blends were heated using direct injection of steam at pressure of 1.5 bar at $85-90^{\circ} \mathrm{C}$ for $5 \mathrm{~min}$. Agitation time of cheese blends was increased in some treatments. The composition of each blend was adjusted for fat by butter or flaxseed oil, $\mathrm{pH}$ by citric acid and moisture content to obtain a final product with $\mathrm{pH}$ value adjusted to 5.6-5.7 to be similar to the processed cheese made according to the Egyptian Standards Specification (2013). The hot product of processed cheese was manually filled into $40 \mathrm{ml}$ glass cups covered well with cup covers, cooled then stored at about $5 \pm 2^{\circ} \mathrm{C}$ for analysis as a fresh and after 1, 2 and 3 months. Three replicates were carried out for each treatment. 
Table 2. Blends recipe $(\mathrm{kg} / 100 \mathrm{~kg})$ of processed cheese with different butter substitution levels with flaxseed oil.

\begin{tabular}{lccccc}
\hline \multirow{2}{*}{\multicolumn{1}{c}{ Ingredient }} & \multicolumn{5}{c}{ Butter substitution level with flaxseed oil } \\
\cline { 2 - 6 } & $\begin{array}{c}\text { Nil } \\
\text { (Control) }\end{array}$ & $25 \%$ & $50 \%$ & $75 \%$ & $100 \%$ \\
\hline Ras cheese & 18 & 18 & 18 & 18 & 18 \\
Skimmed milk curd & 43 & 43 & 43 & 43 & 43 \\
Skimmed milk powder & 2.5 & 2.5 & 2.5 & 2.5 & 2.5 \\
Emulsifying salt & 2.5 & 2.5 & 2.5 & 2.5 & 2.5 \\
Butter & 18.0 & 13.5 & 9.38 & 4.5 & 0.0 \\
Flaxseed oil & 0.0 & 3.6 & 7.2 & 10.8 & 14.4 \\
Water & 16.0 & 16.9 & 17.42 & 18.7 & 19.6 \\
Total & 100 & 100 & 100 & 100 & 100 \\
\hline
\end{tabular}

\section{Analytical methods}

Total solids content, protein and ash contents as well as titratable acidity $\%$ and fatty acids profile were determined as described by AOAC (2016). Fat content was determined using Gerber method as described by Ling (1963). The $\mathrm{pH}$ values were measured using a laboratory digital $\mathrm{pH}$ meter model Adwa 1030 at $20^{\circ} \mathrm{C}$ after calibrating with fresh $\mathrm{pH} 4.0$ and 7.0 standard buffers according to the methods of BSI (1989). Oiling off was determined according to the method outlined by Thomas, (1973). Meltability of the sample of processed cheese was determined according to Olson and Price, (1958) and slightly modified by Savello et al. (1989). The processed cheese spreads and cheese sauce samples were organoleptically evaluated as in IDF (1997).

Biological study was carried out at Animal House Lab, Department of Animal Production; Faculty of Agriculture, AlAzhar University, Cairo, Egypt as described by Beena and Prasad (1997), Carthew et al. (2001) and Zommara et al. (2006). Continuously, at the end of the 28 days experimental period, the rats were killed after overnight fasting by withdrawing blood from the abdominal aorta under light diethyl ether anesthesia. Blood was collected in fine capillary glass tubes and centrifuged at $3.000 \mathrm{rpm}$ for 15 min. to separate serum, which was kept frozen until analysis.
The obtained results were statistically analyzed according to SAS (2001). Duncan's multiple range tests were used to determine the difference among means at the level of 0.05 .

\section{RESULTS AND DISCUSSION}

\section{Sensory quality of processed cheese towards the butter substitution with flaxseed oil}

The panelist scores given in Table (3) revealed that, the products with the 25 and $50 \%$ flaxseed oil addition didn't exhibit any significant difference in terms of the appearance and body \& texture as compared to the control sample. For flavor, no significant differences founded between cheese samples with 25,50 and $75 \%$ flaxseed oil, and the cheese with $25 \%$ flaxseed oil were the nearest to the control sample. For Body \& texture, no significant differences founded between all samples except the sample with $75 \%$ of flaxseed oil as compared to the control sample. For Appearance, no significant differences founded between all samples as compared to the control sample. At all, the best treatment of analog cheese was the cheese with $25 \%$ of flaxseed oil which were the nearest to the control sample followed by $50 \%$ addition of flaxseed oil, but all percentages were acceptable. 
Table 3. Sensory scores of processed cheese as affected by butter substitution level with flaxseed oil.

\begin{tabular}{lccccc}
\hline \multirow{2}{*}{ Criteria score } & \multicolumn{5}{c}{ Butter substitution level with flaxseed oil } \\
\cline { 2 - 6 } & Nil (control) & $\mathbf{2 5 \%}$ & $\mathbf{5 0 \%}$ & $\mathbf{7 5 \%}$ & $\mathbf{1 0 0} \%$ \\
\hline $\begin{array}{l}\text { Appearance } \\
\text { (out of 10 points) }\end{array}$ & $9.0 \mathrm{~A}$ & $8.5 \mathrm{~A}$ & $8.0 \mathrm{~A}$ & $8.0 \mathrm{~A}$ & $8.5 \mathrm{~A}$ \\
$\begin{array}{l}\text { Body \& texture } \\
\text { (out of 40 points) }\end{array}$ & $36.75 \mathrm{~A}$ & $35.80 \mathrm{~A}$ & $35.00 \mathrm{~A}$ & $33.00 \mathrm{~B}$ & $35.50 \mathrm{~A}$ \\
$\begin{array}{l}\text { Flavor } \\
\text { (out of 50 points) }\end{array}$ & $46.0 \mathrm{~A}$ & $44.0 \mathrm{~B}$ & $42.5 \mathrm{~B}$ & $42.5 \mathrm{~B}$ & $39.5 \mathrm{C}$ \\
$\begin{array}{l}\text { Total score } \\
\text { (out of 100 points) }\end{array}$ & $91.75 \mathrm{~A}$ & $88.30 \mathrm{~B}$ & $85.50 \mathrm{C}$ & $83.50 \mathrm{D}$ & $83.50 \mathrm{D}$ \\
\hline
\end{tabular}

Different superscripts at the same raw are significantly different $(\mathrm{P} \leq 0.05)$.

Chemical properties of processed cheese towards the butter substitution with flaxseed oil

The results present in Table (4) indicated that, there were significant differences among the control and all treatments in DM, protein, fat and Ash contents. These differences may be due to the variations in the agitation time sometimes required as well as the differences between butter and flaxseed oil in their moisture contents and rather their lipid contents. Whereas, protein and fat contents increased as the butter was substituted with flaxseed oil. On the contrary, the ash content of the cheese spreads decreased with the increase in the percentage of flaxseed oil instead of butter. The flaxseed oil addition to the processed cheese led to increase the total volatile fatty acids content.

As a general, The DM content of all experimental cheese samples are in accordance to the legal standard of EOSQ. These results trends are in agreement with those of Shalaby and Yasin (2013).

Table 4. Chemical composition of processed cheese as affected by butter substitution level with flaxseed oil.

\begin{tabular}{lccccc}
\hline \multirow{2}{*}{ Component } & \multicolumn{5}{c}{ Butter substitution level with flaxseed oil } \\
\cline { 2 - 6 } & Nil (control) & $25 \%$ & $50 \%$ & $75 \%$ & $100 \%$ \\
\hline Dry matter $(\mathrm{DM}) \%$ & $42.08 \mathrm{E}$ & $44.72 \mathrm{~A}$ & $43.17 \mathrm{D}$ & $44.57 \mathrm{~B}$ & $43.8 \mathrm{C}$ \\
Protein $(\mathrm{TN} \times 6.38) \%$ & $12.12 \mathrm{E}$ & $12.31 \mathrm{C}$ & $12.19 \mathrm{D}$ & $12.36 \mathrm{~B}$ & $12.82 \mathrm{~A}$ \\
Fat \% & $20.90 \mathrm{E}$ & $21.20 \mathrm{D}$ & $21.40 \mathrm{C}$ & $22.10 \mathrm{~B}$ & $22.85 \mathrm{~A}$ \\
Fat/ DM \% & $49.67 \mathrm{~B}$ & $47.41 \mathrm{D}$ & $49.57 \mathrm{C}$ & $49.58 \mathrm{C}$ & $52.17 \mathrm{~A}$ \\
Ash \% & $4.17 \mathrm{~A}$ & $4.07 \mathrm{~B}$ & $4.00 \mathrm{C}$ & $4.06 \mathrm{~B}$ & $3.83 \mathrm{D}$ \\
TVFA ml/100g & $140 \mathrm{D}$ & $140 \mathrm{D}$ & $146 \mathrm{C}$ & $170 \mathrm{~B}$ & $190 \mathrm{~A}$ \\
\hline
\end{tabular}

TN: Total nitrogen, TVFA: Total volatile fatty acids, Different superscripts at the same raw are significantly different $(\mathrm{P} \leq 0.05)$.

Titratable acidity percent and $\mathrm{pH}$ value of processed cheese towards the butter substitution with flaxseed oil during cold storage period

The obtained results for acidity in Table (5) showed that the titratable acidity \% of studied treatments decreased regularly throughout storage and with the increase the percentage of flaxseed oil addition, but the acidity increased by storage at $5 \pm 2^{\circ} \mathrm{C}$ in all samples. The obtained data also showed that no significant difference found in acidity between the control sample and the cheese samples with $25 \%$ and $50 \%$ of flaxseed oil after 1 month of storage at $5 \pm 2^{\circ} \mathrm{C}$. Also no significant difference found in acidity among the control sample and cheese with $25 \%$ of flaxseed oil after 2 months of storage at $5 \pm 2^{\circ} \mathrm{C}$. No significant difference found in acidity among the cheese with $50 \%$ and $75 \%$ of flaxseed oil after 2 months of storage at $5 \pm 2^{\circ} \mathrm{C}$, also between samples with $25 \%$ and $50 \%$ of flaxseed oil after 3 months at $5 \pm 2^{\circ} \mathrm{C}$.

Data in Table (5) indicated also a high rate of variable increase in the $\mathrm{pH}$ value of the processed cheese made with increasing 
Table 5. Titratable acidity percent and $\mathrm{pH}$ value of processed cheese as affected by butter substitution level with flaxseed oil during storage at $5 \pm 2^{\circ} \mathrm{C}$.

\begin{tabular}{|c|c|c|c|c|c|}
\hline \multirow{3}{*}{$\begin{array}{l}\text { Cold storage period } \\
\text { (month) }\end{array}$} & \multicolumn{5}{|c|}{ Butter substitution level with flaxseed oil } \\
\hline & Nil (control) & $25 \%$ & $50 \%$ & $75 \%$ & $100 \%$ \\
\hline & \multicolumn{5}{|c|}{ Titratable acidity $\%$} \\
\hline Fresh & $0.85 \mathrm{Ad}$ & $0.83 \mathrm{Bd}$ & $0.77 \mathrm{Cd}$ & $0.76 \mathrm{Dd}$ & $0.75 \mathrm{Dd}$ \\
\hline 1 & 0.99Ac & $0.98 \mathrm{Ac}$ & $0.98 \mathrm{Ac}$ & $0.95 \mathrm{Bc}$ & $0.83 \mathrm{Cc}$ \\
\hline 2 & $1.22 \mathrm{Ab}$ & $1.22 \mathrm{Ab}$ & $1.18 \mathrm{Bb}$ & $1.17 \mathrm{Bb}$ & $1.05 \mathrm{Cb}$ \\
\hline \multirow[t]{2}{*}{3} & $1.46 \mathrm{Aa}$ & $1.42 \mathrm{Ba}$ & $1.42 \mathrm{Ba}$ & $1.37 \mathrm{Ca}$ & $1.18 \mathrm{Da}$ \\
\hline & \multicolumn{5}{|c|}{ pH value } \\
\hline Fresh & $6.16 \mathrm{Da}$ & $6.16 \mathrm{Da}$ & $6.26 \mathrm{Ca}$ & $6.28 \mathrm{Ba}$ & 6.30Aa \\
\hline 1 & $6.00 \mathrm{Db}$ & $6.10 \mathrm{Cb}$ & $6.11 \mathrm{Cb}$ & $6.15 \mathrm{Bb}$ & $6.20 \mathrm{Ab}$ \\
\hline 2 & $5.86 \mathrm{Dc}$ & $5.86 \mathrm{Dc}$ & $5.90 \mathrm{Cc}$ & $5.96 \mathrm{Bc}$ & 5.99Ac \\
\hline 3 & 5.59Ed & $5.66 \mathrm{Dd}$ & $5.70 \mathrm{Cd}$ & $5.76 \mathrm{Bd}$ & $5.84 \mathrm{Ad}$ \\
\hline
\end{tabular}

Different capital superscripts at the same column are significantly different $(\mathrm{P} \leq 0.05)$. Different small superscripts at the same raw are significantly different $(\mathrm{P} \leq 0.05)$.

percentages of the flaxseed oil whether, when fresh and during storage conditions at $5 \pm 2^{\circ} \mathrm{C}$. The $\mathrm{pH}$ value of processed cheese made by using $25 \%$ of flaxseed oil did not appeared any significant differences compared to the control sample at zero time and after 2 months. Also no significant differences between cheese samples with $25 \%$ and $50 \%$ of flaxseed oil after 1 month of cold storage period (CSP). While the $\mathrm{pH}$ values of all samples of processed cheese showed significant differences with advanced storage as compared with the fresh cases. That difference was probably due to the action of emulsifying salt as reported by Caric and Kalab (1993). It may be also due to the limited growth and activity of cheese microflora as mentioned by Abd El-Salam et al. (1996) and Metwally et al. (1996).

Fatty acids composition of butter fat, flaxseed oil and processed cheese towards the butter substitution with flaxseed oil

Data in Table (6) exhibited that in the processed cheese made with flaxseed oil, the total saturated fatty acids decreased and therefore the total unsaturated increased with the rise in the addition percentage of flaxseed oil in spreads, when compared to the control sample. So, the ratio of total saturated to unsaturated fatty acids decreased with the rise in the addition percentage of flaxseed oil in spreads. The current results (Table 8) evident that the total short chain fatty acids in processed cheese spreads decreased with increasing the addition percentage of flaxseed oil in spreads, while the total long chain fatty acids increased when compared with control sample. The incorporation of the flaxseed oil into the processed cheese caused a high increment in Linoleic, Linolenic and Arachidic acids as the incorporation level increased.

Rheological properties of processed cheese towards the butter substitution with flaxseed oil

\section{Oiling off}

From the obtained results of Table (7), it could be observed that the processed cheese that made with 25 and 50\% flaxseed oil were the best levels for oil separation at all and the cheese with $25 \%$ flaxseed oil was the nearest to the control sample at zero time and during CSP. No significant differences between the control sample and the cheese samples made with 25 and 50\% flaxseed oil at 1, 2 and 3 months of storage. While the cheese made using $100 \%$ of flaxseed oil recorded the highest oiling off values along three months of CSP. The high separation of fat in cheese that made with incorporating $100 \%$ of flaxseed oil may be due to the high level of flaxseed oil which need to especial process and appropriate emulsifying salt for emulsification of fat in the protein matrix in the cheese. In this concern, Dalglish and Low (1988) reported that emulsifiers and stabilizers led to emulsification of fat in protein matrix. Saad et al. (2016) mentioned that the low degree of oiling off could be attributed to the high stability of the emulsified material and the good fat emulsification in the texture. The oil separation values of all treatments even in control tended to increase as storage 
Table 6. Fatty acids profile of processed cheese towards the butter substitution with flaxseed oil.

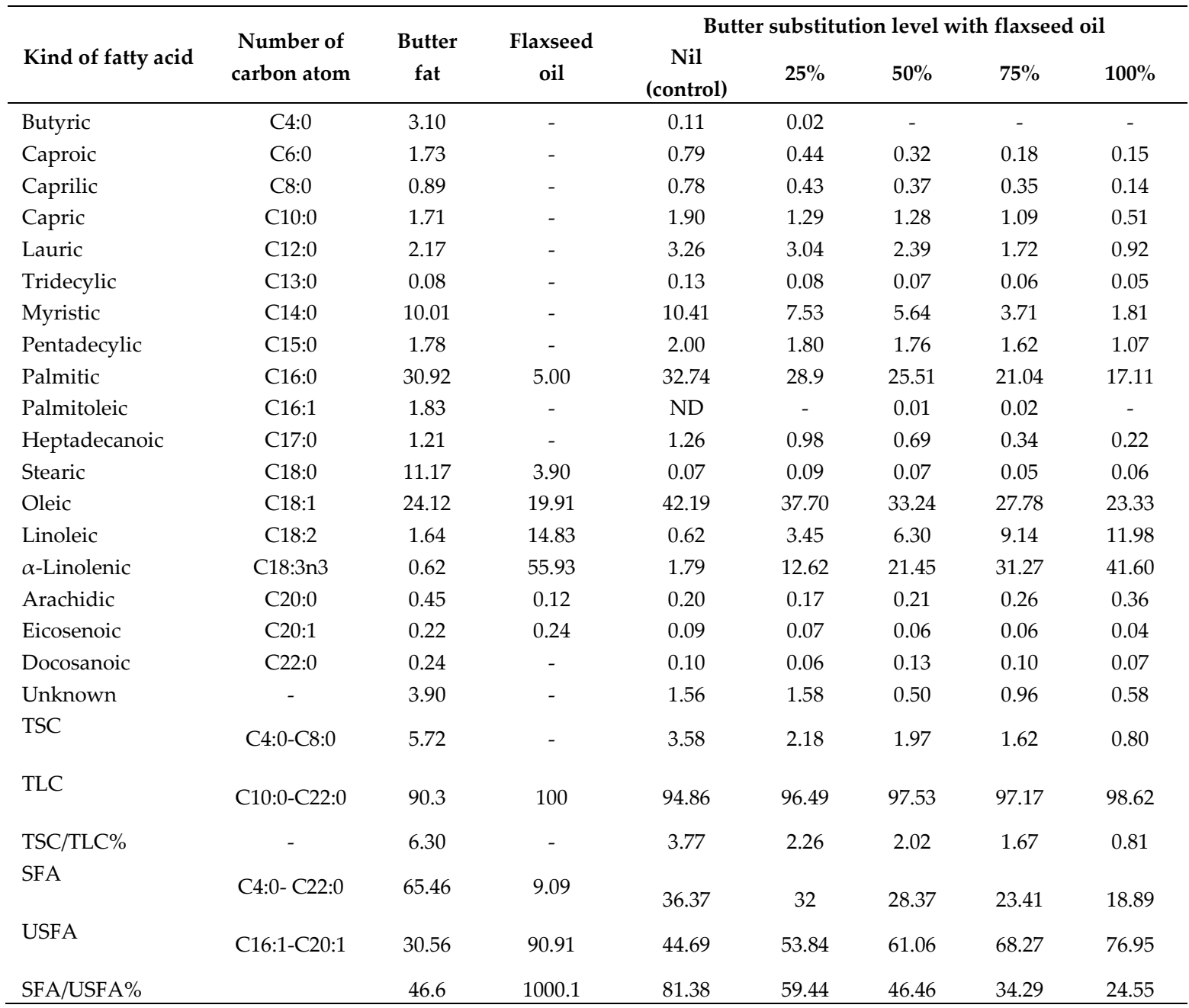

TSC: Total short chain, TLC: Total long chain, USFA: Unsaturated fatty acids, SFA: Unsaturated fatty acids, ND: Not detected.

period progressed. Also the oil separation values increased with increasing the flaxseed oil ratio in spreads. The control sample recorded the lowest value; these results are in agreement with Shamsia et al. (2011).

\section{Meltability index}

Meltability of the processed cheese spreads was expressed as the distance of cheese flow in millimeter. The current results of Table (8) exhibited that processed cheese made with $100 \%$ of flaxseed oil had the highest meltability index, while spreads containing $25 \%$ of flaxseed oil had the lowest values at zero time and throughout CSP as compared to the control sample. The melting index values of all samples tended to increase as the storage period extended. This difference among the treatments and control may be due to the orientation of the $\mathrm{pH}$ value during storage. The results of control cheese during storage are agreement with those of Awad (2010). Mohamed, et al. (2011) reported that the degree of meltability of the processed cheese could be affected by the ingredients of the products, and / or the increased rigidity and reduced flowing rate could be attributed to the reduction of the fat granules size. Solowiej (2007) found out that the viability of fusion is related to the increase in $\mathrm{pH}$ value and the smoothness in the texture and the high degree of the disintegration of casein and the reduction of fat emulsification. The soft texture of the processed cheese together with an increase in the moisture content could also leads to increase the meltability. 
Table 7. Oiling off of processed cheese as affected by butter substitution level with flaxseed oil during storage at $5 \pm 2^{\circ} \mathrm{C}$

\begin{tabular}{cccccc}
\hline \multirow{2}{*}{$\begin{array}{c}\text { Cold storage } \\
\text { period } \\
\text { (month) }\end{array}$} & $\begin{array}{c}\text { Nil } \\
\text { (control) }\end{array}$ & $\mathbf{2 5 \%}$ & $\mathbf{5 0 \%}$ & $\mathbf{7 5 \%}$ & $\mathbf{1 0 0 \%}$ \\
\hline Fresh & $4.25 \mathrm{Dd}$ & $7.3 \mathrm{Cd}$ & $15.2 \mathrm{Cd}$ & $25.8 \mathrm{Bd}$ & $40.6 \mathrm{Ad}$ \\
1 & $7.2 \mathrm{Cc}$ & $10 \mathrm{Cc}$ & $17.6 \mathrm{Cc}$ & $55.9 \mathrm{Bc}$ & $73.8 \mathrm{Ac}$ \\
2 & $9.4 \mathrm{Cb}$ & $14 \mathrm{Cb}$ & $19.4 \mathrm{Cb}$ & $80.2 \mathrm{Bb}$ & $99.3 \mathrm{Ab}$ \\
3 & $11.3 \mathrm{Ca}$ & $18.3 \mathrm{Ca}$ & $20.8 \mathrm{Ca}$ & $106.8 \mathrm{Ba}$ & $128.2 \mathrm{Aa}$ \\
\hline
\end{tabular}

Means followed by the same capital letters in the same columns; and values followed by the same small letters in the same row are not significantly different $(\mathrm{P} \leq 0.05)$.

Table 8. Meltability index of processed cheese as affected by butter substitution level with flaxseed oil during storage at $5 \pm 2^{\circ} \mathrm{C}$.

\begin{tabular}{cccccc}
\hline \multirow{2}{*}{$\begin{array}{c}\text { Cold storage period } \\
\text { (month) }\end{array}$} & \multicolumn{4}{c}{ Butter substitution level with flaxseed oil } \\
\cline { 2 - 6 } & $\begin{array}{c}\text { Nil } \\
\text { (control) }\end{array}$ & $\mathbf{2 5 \%}$ & $\mathbf{5 0 \%}$ & $\mathbf{7 5 \%}$ & $\mathbf{1 0 0 \%}$ \\
\hline Fresh & $57 \mathrm{Ec}$ & $65 \mathrm{Dc}$ & $85 \mathrm{Cc}$ & $88 \mathrm{Bb}$ & $93 \mathrm{Ac}$ \\
1 & $58 \mathrm{Dbc}$ & $68 \mathrm{Cb}$ & $90 \mathrm{Bbc}$ & $95 \mathrm{Bb}$ & $110 \mathrm{Ab}$ \\
2 & $61 \mathrm{Dab}$ & $70 \mathrm{Dab}$ & $94 \mathrm{Cab}$ & $109 \mathrm{Ba}$ & $122 \mathrm{Aab}$ \\
3 & $63 \mathrm{Da}$ & $72 \mathrm{Da}$ & $98 \mathrm{Ca}$ & $115 \mathrm{Ba}$ & $133 \mathrm{Aa}$ \\
\hline
\end{tabular}

Means followed by the same capital letters in the same columns; and values followed by the same small letters in the same row are not significantly different $(\mathrm{P} \leq 0.05)$.

\section{Biological experiment}

\section{Growth parameters of Albino rats}

Growth parameters of rats fed on processed cheese containing flaxseed oil are presented in (Table, 9). It was obvious from these data that at the end of the experiment (28 days), rats were received processed cheese treatments gained higher body weights than those fed only dry diet (control I). Moreover, as shown from the same data (Table, 9) that the increases in body weight gain for all tested rats ranged from $48 \mathrm{~g}$ to $92 \mathrm{~g}$. Also, rats fed on dry diet (control I) showed the least final body weight, actually $174 \mathrm{~g}$, while those received processed cheese containing $25 \%$ flaxseed oil gained the highest final body weight, being $219 \mathrm{~g}$. This finding suggests that type of diet significantly affect the growth parameters of rats. In this respect, the same trend of results was previously reported by Mohamed and Afifi (2011); Tou et al. (2011) and Boulbaroud et al. (2012). Additionally, the present results revealed that there were no considerable variations between growth rate ( body weight gain $\mathrm{g} /$ feeding period) and food efficiency (growth rate $\mathrm{g} / \mathrm{d} /$ food intake $\mathrm{g} / \mathrm{d}$ ) among different treatments, these results in agreement with those reported by Vijaimohan et al. (2006); El-
Waseif (2008) and Mohamed and Afifi (2011).

\section{Blood serum profile of Albino rats}

Total and high density lipoprotein cholesterols

Results of total and high density lipoprotein (HDL)-cholesterols levels are summarized in Table (10). The obtained results indicate that serum cholesterol level in control II (dry diet + processed cheese) was significantly higher than in control I (only dry diet) by $42.75 \%$ at the end of the experiment. Compared with group fed dry diet + processed cheese (control II), the total serum cholesterol was lowered by 12.26 and $31.04 \%$ in the group fed on processed cheese containing $25 \%$ flaxseed oil and processed cheese containing $75 \%$ flaxseed oil, respectively. These results are in agreement with those reported by Lucas et al. (2004), Boulbaroud et al. (2012) and Soltan (2012). In this respect the role of flaxseed oil in lowering total cholesterol explained by Kris-Etherton, et al. (2002), Moghadasian (2008), Brenna et al. (2009) and Tzang et al. (2009), who reported that lowering effect for flaxseed oil may be due to increase omega-3 long chain polyunsaturated fatty acid in rats by a conversion of ALA in flaxseed oil to 
Table 9. Growth parameters of rats fed on processed cheese containing flaxseed oil as butter substitute.

\begin{tabular}{|c|c|c|c|c|}
\hline \multirow{2}{*}{ Parameter } & \multirow{2}{*}{$\begin{array}{c}\text { Base } \\
\text { Diet } \\
\text { (control I) }\end{array}$} & \multicolumn{3}{|c|}{$\begin{array}{c}\text { Butter substitution level with } \\
\text { flaxseed oil }\end{array}$} \\
\hline & & $\begin{array}{c}\text { Nil } \\
\text { (control II) }\end{array}$ & $25 \%$ & $75 \%$ \\
\hline Initial body weight (g) & 126 & 125 & 127 & 126 \\
\hline Final body weight (g) & $174 \mathrm{~B}$ & $217 \mathrm{~A}$ & $219 \mathrm{~A}$ & $215 \mathrm{~A}$ \\
\hline$\%$ change to normal control & ----- & 24.71 & 25.86 & 23.56 \\
\hline Food intake (g/day) & 12 & 15 & 15 & 15 \\
\hline Body weight gain (g) & 48 & 92 & 92 & 89 \\
\hline Body weight gain (\%) & 38.10 & 73.60 & 72.44 & 70.63 \\
\hline Growth rate (g/day) & $1.71 \mathrm{~B}$ & $3.29 \mathrm{~A}$ & $3.29 \mathrm{~A}$ & $3.18 \mathrm{~A}$ \\
\hline Food efficiency & 0.14 & 0.22 & 0.22 & 0.21 \\
\hline
\end{tabular}

The means within the same row having different superscript are significantly varied $(\mathrm{P} \leq 0.05)$. Means with the same letter are not significantly different.

Table 10. Levels of serum total and high density lipoprotein cholesterols of rats fed on processed cheese containing flaxseed oil as butter substitute.

\begin{tabular}{|c|c|c|c|c|}
\hline \multirow[b]{2}{*}{ Parameter } & \multirow{2}{*}{$\begin{array}{c}\text { Base } \\
\text { Diet } \\
\text { (control I) }\end{array}$} & \multicolumn{3}{|c|}{ Butter substitution level with flaxseed oil } \\
\hline & & $\begin{array}{c}\text { Nil } \\
\text { (control II) }\end{array}$ & $25 \%$ & $75 \%$ \\
\hline $\begin{array}{l}\text { Initial total cholesterol } \\
(\mathrm{mg} / \mathrm{dL})\end{array}$ & 77.12 & 74.97 & 78.19 & 75.08 \\
\hline $\begin{array}{l}\text { Final total cholesterol } \\
\qquad(\mathrm{mg} / \mathrm{dL})\end{array}$ & $85.34 \mathrm{C}$ & $121.82 \mathrm{~A}$ & $106.88 \mathrm{~B}$ & $84.01 \mathrm{C}$ \\
\hline$\%$ change to control II & -29.95 & ------ & -12.26 & -31.04 \\
\hline $\begin{array}{l}\text { Initial HDL-cholesterol } \\
(\mathrm{mg} / \mathrm{dL})\end{array}$ & 42.46 & 41.91 & 43.17 & 42.33 \\
\hline $\begin{array}{l}\text { Final HDL-cholesterol } \\
(\mathrm{mg} / \mathrm{dL})\end{array}$ & $45.94 \mathrm{C}$ & $59.92 \mathrm{~A}$ & $58.27 \mathrm{~A}$ & $49.75 \mathrm{~B}$ \\
\hline$\%$ change to control II & -23.33 & ------ & -2.75 & -16.97 \\
\hline
\end{tabular}

The means within the same row having different superscript are significantly varied $(\mathrm{P} \leq 0.05)$. Means with the same letter are not significantly different.

eicosapentaenoic acid (EPA) and docosahexaenoic acid (DHA). EPA+DHA have been associated with a reduced risk of coronary heart diseases. From these data it could be noticed that there was significant difference in the serum HDL-cholesterol levels between all treatments at the end of the 4-weeks experimental period. Also, the present results declared that serum HDLcholesterol levels were increased at the end of the experiment, the increases values varied from $8.20 \%$ to $42.97 \%$, as compared with their corresponding initial values. However, comparing the obtained results of control treatment (control I), showed variable increasing in HDL-cholesterol values ranged from $8.29 \%$ to $30.43 \%$. Moreover, rats received processed cheese containing $25 \%$ flaxseed oil and those received processed cheese containing $75 \%$ flaxseed oil increased the levels of HDLcholesterol by $34.98 \%$ and $17.53 \%$, respectively. However, HDL-cholesterol levels are anti-atherogenic, while reduced levels are associated with increased risk for coronary artery disease as previously explained by Zilva and Mayne (1991). These results are in agreement with those reported by Morise et al. (2004), Boulbaroud et al. (2012), EL-Sahar and Abed EL- Rahman (2014) and Aly-Aldin et al. (2015).

\section{Serum triglycerides, low and very low density lipoprotein cholesterols}

The levels of serum triglycerides in rats fed on processed cheese containing flaxseed oil are present in Table (11). It was evident from the data that, processed cheese (control II) greatly increased serum triglycerides in rats thereon fed by about $65.74 \%$ as compared to control I (dry diet). On the other hand, the levels of serum triglycerides in rats fed on processed 
Table 11. Serum triglycerides, low and very low density lipoprotein cholesterols of rats fed on processed cheese containing flaxseed oil as butter substitute.

\begin{tabular}{|c|c|c|c|c|}
\hline \multirow{2}{*}{ Parameter } & \multirow{2}{*}{$\begin{array}{c}\text { Base } \\
\text { Diet } \\
\text { (control I) }\end{array}$} & \multicolumn{3}{|c|}{ Butter substitution level with flaxseed oil } \\
\hline & & $\stackrel{\text { Nil }}{\text { (control II) }}$ & $25 \%$ & $75 \%$ \\
\hline Initial triglycerides $(\mathrm{mg} / \mathrm{dL})$ & 60.06 & 58.86 & 59.71 & 59.80 \\
\hline Final triglycerides (mg/dL) & $65.32 \mathrm{C}$ & $108.26 \mathrm{~A}$ & $83.68 \mathrm{~B}$ & $65.11 \mathrm{C}$ \\
\hline \% change to control II & -39.66 & ------ & -24.58 & -39.86 \\
\hline $\begin{array}{l}\text { Initial LDL-cholesterol } \\
(\mathrm{mg} / \mathrm{dL})\end{array}$ & 22.65 & 21.29 & 23.08 & 20.79 \\
\hline $\begin{array}{l}\text { Final LDL-cholesterol } \\
(\mathrm{mg} / \mathrm{dL})\end{array}$ & $26.34 \mathrm{C}$ & $40.25 \mathrm{~A}$ & $31.87 \mathrm{~B}$ & $21.24 \mathrm{D}$ \\
\hline$\%$ change to control II & -34.56 & ------ & -20.82 & -47.23 \\
\hline $\begin{array}{l}\text { Initial vLDL-cholesterol } \\
(\mathrm{mg} / \mathrm{dL})\end{array}$ & 12.01 & 11.77 & 11.94 & 11.96 \\
\hline $\begin{array}{l}\text { Final vLDL-cholesterol } \\
(\mathrm{mg} / \mathrm{dL})\end{array}$ & $13.06 \mathrm{C}$ & $21.65 \mathrm{~A}$ & $16.74 \mathrm{~B}$ & $13.02 \mathrm{C}$ \\
\hline$\%$ change to control II & -39.68 & ------ & -22.68 & -39.86 \\
\hline
\end{tabular}

The means within the same row having different superscript are significantly varied $(\mathrm{P} \leq 0.05)$. Means with the same letter are not significantly different.

cheese containing $25 \%$ flaxseed oil and those received processed cheese containing $75 \%$ flaxseed oil were lower than those fed on processed cheese (control II). However, the reduction in triglyceride levels due to rats feeding on 25 and $75 \%$ flaxseed oil cheeses were 24.58 and $39.86 \%$, respectively. These results are in agreement with those mentioned by Riediger et al. (2008), EL-Sahar and Abed EL- Rahman (2014) and Khan and Makki (2017). Furthermore, Soltan (2012) concluded that the main effect of dietary $n-3$ fatty acids on plasma lipids and lipoproteins in general is reduction in plasma triglycerides by $20 \%$ $50 \%$ in healthy subjects and even more in subjects with hypertriglyceridemia. In this respect De Caterina et al. (2007) reported that $n-3$ fatty acids reduced plasma triglyceride. n-3 fatty acid suppressed hepatic lipogemesis and reduced circulating triglyceride levels. Furthermore, since a high blood LDLcholesterol is associated with increased risk of atherosclerosis and cardiovascular disease, any product that lowers this level is of potential value. Robbins and Cortan (1981) mentioned that, as $70 \%$ of total cholesterol is HDL-cholesterol. The results appeared also that processed cheese (control II) markedly increase LDLcholesterol by $52.81 \%$ as compared to control I (dry diet). Compared with group fed on processed cheese (control II), the
LDL-cholesterol were lowered by 20.82 and $47.23 \%$ in the group fed on processed cheese containing $25 \%$ flaxseed oil and processed cheese containing $75 \%$ flaxseed oil, respectively. Continuously, it was evident that the latter ( $75 \%$ flaxseed oil) was more effective in reducing serum LDLcholesterol, which ranked the lowest value actually $21.24 \mathrm{mg} / \mathrm{dL}$. However, this reduction may be attributed to the reduction in serum total cholesterol. These results are in agreement with Morise et al. (2004), Vijaimohan et al. (2006), Boulbaroud et al. (2012) and Kawakami et al. (2015). It is of interest to mention that coronary artery diseases tend to develop in those patients who have increased serum LDLcholesterol as previously reported by Whitby et al. (1984). Moreover, Zilva and Mayne (1991) declared that, with increasing serum level of LDL - cholesterol, the scavenger cells taken up larger amounts of the circulating lipoprotein and become overloaded with cholesterol named "foam cells", this cells become the hallmark of the atherosclerotic plague. Early, Tietz (1986) found that, reduction in the removal of LDL from serum causes elevated serum levels of LDL and increased uptake of LDL by macrophages and smooth muscle cells deposits in arterial walls and consequently, premature atherosclerosis. In general, for each $1 \mathrm{mg} / \mathrm{dL}$ decrease in LDL- cholesterol in the plasma there is approximately a $2 \%$ 
decrease in mortality from atherosclerotic heart disease. The obtained results indicate also that serum very low density lipoprotein (vLDL)-cholesterol level in control II (processed cheese) was significantly higher than in control I (only dry diet) by $65.77 \%$ at the end of the experiment. Compared with group fed on processed cheese (control II), the vLDLcholesterol was lowered by 22.68 and $39.86 \%$ in groups of 25 and $75 \%$ flaxseed oil cheeses, respectively. Continuously, it was evident that, the latter $(75 \%$ flaxseed oil) was more effective in reducing serum vLDL-cholesterol, which possesses the least figure actually $13.02 \mathrm{mg} / \mathrm{dL}$. However, this reduction may be attributed to the reduction in serum total cholesterol. These results are in agreement with previous results of Morise et al. (2004); Vijaimohan et al. (2006) and Fadlalla et al. (2013).

Generally, the decreases in serum triacylglycerol, LDL and vLDL cholesterol of rats fed on cheese containing flaxseed oil have been explained by Strolien et al. (2007), who suggested that the decrease in triglyceride levels attributed to the lowering effect of omega- 3 fatty acids has been mainly ascribed to reduce hepatic synthetic of vLDL cholesterol. Omega-3 fatty acid suppressed hepatic lipogenesis and reduced circulating triglycerides level. Furthermore, Morise et al. (2005) observed that a higher ALA intake decrease cholesterol content in liver, however, increase in the feces. The reduced hepatic cholesterol content was accounted for higher cholesterol secretion into bile thus leading to a depletion of into intrahepatic pool of cholesterol.

\section{Atherogenic index}

The effects of processed cheese containing flaxseed oil on atherogenic indexes were carried out, also the ratio between LDL or HDL- cholesterol and total cholesterol, in addition to LDL / HDL ratio were calculated and data obtained summarized in Table (12). As a matter of fact, the atherogenic index is an indication for the susceptibility for atherosclerosis. Many studies explored the relationship between dietary factors and risk for atherosclerosis particularly, the regulation of cholesterol and lipoprotein metabolism by the type and amount of dietary fat (Mancini and Parillo, 1991; Nishina et al., 1993). In general, diets rich in mono and polyunsaturated fat decrease plasma cholesterol levels, while, diets rich in saturated fat in particular lauric, myristic and palmitic acids are positively correlated to plasma cholesterol level (Nordov and Goodnight, 1990). It is clear from these results that, processed cheese (control II), led to obvious increases in atherogenic indices 1 and 2, in addition to LDL /HDL ratio by a mean values of $6.80,20.40$ and $17.14 \%$ respectively, and lowered HDL/total cholesterol ratio by $8.55 \%$ as compared to those fed on dry diet (control I). Continuously, the data in Table (12) indicate that the values of atherogenic indexes 1, 2 and LDL/ HDL ratio were decreased by $(9.70,19.26$ and $16.58 \%)$ and $(23.33,33.30$ and $36.44 \%)$ and increased in HDL/total cholesterol ratio by 10.77 and $20.33 \%$ for groups of rats fed on 25 and $75 \%$ flaxseed oil cheeses, respectively, as compared with group fed on processed cheese (control II), Similar trend of results was previously reported by Dupasquier et al. (2007) and Gruenfelder (2014), who demonstrated that dietary flaxseed can inhibit atherosclerosis through a reduction of circulating cholesterol levels and, at a cellular level, via anti-proliferative and anti-inflammatory actions.

\section{CONCLUSIONS}

This research studied the improvement of nutritional and potential therapeutic value of processed cheese using flaxseed oil as butter substitute because of its high nutritional and health value. From these results, it could be recommended flaxseed oil as butter partial substitute in processed cheese manufacture up to $75 \%$. 
Table 12. Atherogenic index of rats fed on processed cheese containing flaxseed oil as butter substitute.

\begin{tabular}{lcccc}
\hline \multirow{2}{*}{ Parameter } & \multirow{2}{*}{$\begin{array}{c}\text { Base } \\
\text { Diet }\end{array}$} & \multicolumn{3}{c}{ Butter substitution level with flaxseed oil } \\
\cline { 3 - 5 } & (control I) & $\begin{array}{c}\text { Nil } \\
\text { (control II) }\end{array}$ & $25 \%$ & $75 \%$ \\
\hline $\begin{array}{l}\text { Final HDL/Total } \\
\text { cholesterol ratio }\end{array}$ & $0.538 \mathrm{~B}$ & $0.492 \mathrm{C}$ & $0.545 \mathrm{~B}$ & $0.592 \mathrm{~A}$ \\
$\begin{array}{l}\text { Atherogenic index 1 } \\
\text { Atherogenic index 2 }\end{array}$ & $0.309 \mathrm{~B}$ & $0.330 \mathrm{~A}$ & $0.298 \mathrm{~B}$ & $0.253 \mathrm{C}$ \\
\% LDL/HDL & $0.858 \mathrm{~B}$ & $1.033 \mathrm{~A}$ & $0.834 \mathrm{~B}$ & $0.689 \mathrm{C}$ \\
\hline
\end{tabular}

The means within the same row having different superscript are significantly varied $(\mathrm{P} \leq 0.05)$. Means with the same letter are not significantly different. Atherogenic index 1: LDL/Total cholesterol. Atherogenic index 2: (Total cholesterol-HDL)/HDL.

\section{REFERENCES}

Abd El-Salam, M.H., Al-Khamy, A.F., El-Garawany, G.A., Khader, A., 1996. Composition and rheological properties of processed cheese spread as affected by the level of added whey protein concentrate and emulsifying salt. Egypt. J. Dairy Sci., 24, 309-322.

Aly-Aldin, M.M., Mansour, E.H., Rahma, E.H., Abo El-Fath, A.E.E., El-Bedawey, F.A., El-Habashy, M.M., 2015. Protective role of flaxseed oil on hypercholesterolemic rats. Biolife, 3:794-801.

AOAC, 2016. Association of Official Analytical Chemists. Official Methods of Analysis of AOAC International - 20 th Ed. Benjamin Franklin, Washington D.C., USA.

Awad, R.A., Salama, W.M., 2010. Development of a novel processed cheese product containing fermented barley. Egypt. J. Dairy Sci., 38, 95103.

Beena, A., Prasad, B., 1997. Effect of yoghurt and bifidus yoghurt fortified with skim milk powder, condensed whey and lactosehydrolyzed condensed whey on serum cholesterol and triacylglycerols level on rats. J. Dairy Res., 64, 453-457.

Bhatty, R.S., 1995. Nutritional composition of whole flaxseed and flaxseed meal. In: Cunnane, S.C., Thompson, L.H. Eds. Flaxseed in Human Nutrition. AOCS Press, Champaign, pp 22-45

Boulbaroud, S., El-Hessni, A., Azzaoui, F.Z., Mesfioui, A., 2012. Sesame seed oil and flaxseed oil affect plasma lipid levels and biomarkers of bone metabolism in ovariectomized Wistar rats. Biol. Med., 4, 102-110.

Brenna, J.T., Salem, N., Sinclair, A.J., Cunnane, S.C., 2009. $\alpha$-Linolenic acid supplementation and conversion to $\mathrm{n}-3$ long-chain polyunsaturated fatty acids in humans. Prostag. Leukot. Essent. Fatty acids, 80, 85-91.

BSI, 1990. British Standards Institution. Testing aggregates. General requirements for apparatus and calibration. BS 812: Part 100, BSI, London, UK.
Caric, M., Kalab, M., 1993. Processed Cheese Products. Ch. 15. Cheese Chemistry, Physics and Microbiology". 2nd Ed. (P.F. Fox, Ed.), Chapman \& Hall, London, UK.

Carthew, P., Baldrick, P., Hepburn, P.A., 2001. An assessment of the carcinogenic potential of shea oleine in the rat. Food Chem. Toxicol., 39, 807815

Dalglish, D.G., Law, A.J.R., 1988. Sodium caseinate composition and properties of different preparations. Int. J. Dairy Technol., 41, 1-4.

De Caterina, R., Madonna, R., Bertolotto, A., Schmidt, E.B., 2007. N-3 fatty acids in the treatment of diabetic patients. Diabetes Care, 30, 1012-1026.

Dupasquier, C.M., Dibrov, E., Kneesh, A.L., Cheung, P.K., Lee K.G., Alexander, H.K., Pierce, G.N., 2007. Dietary flaxseed inhibits atherosclerosis in the LDL receptor-deficient mouse in part through antiproliferative and antiinflammatory actions. Am. J. Physiol. Heart Circ. Physiol., 293, 2394-2402.

EL-Sahar, E.G.E., Abed EL-Rahman, A.M.M., 2014. Study on the biological effect of use flaxseed oil as a source of fat on the Biomarkers of experimental rats. J. Am. Sci., 10, 116-123.

Fadlalla, E.A.S., Abd Elal, Z.S., Seddik, A.A., 2013. Protective effect of olive, almond and flaxseed oil against carbon tetrachloride-induced hepatotoxicity in rat models. Afr. J. Biol. Sci., 6 , 243-259.

German, J.B., Gibson, R.A., Krauss, R.M., Nestel, P., Lamarche, B., Van Staveren, W.A., Destaillats, F., 2009. A reappraisal of the impact of dairy foods and milk fat on cardiovascular disease risk. Eur. J. Nutr., 48, 191-203.

Gruenfelder, C.A. 2014. Sensory Evaluation of Hearthealthy Foods Enriched with Omega-3 Fats from Fish Oil. PhD, College of Saint Elizabeth, N.J., USA.

Guinee, T.P., Carić, M., Kalab, M., 2004. Pasteurized processed cheese and substitute/imitation cheese products.In: Fox, P.F., McSweeney, P.L.H., Cogan, T.M., Guinee, T.P., Eds., Cheese: Chemistry, Physics and 
Microbiology. Elsevier Ltd, $2^{\text {nd }}$ Ed., pp. 349394.

IDF, 1997 IDF guideline. Standard 99 C. Sensory evaluation of dairy products by scoring reference method. International Dairy Federation. Brussels, Belgium.

Kalra, E.K., 2003. Nutraceutical-definition and introduction. AAPS Pharm. Sci., 5, 27-28.

Kawakami, Y., Yamanaka-Okumura, H., NaniwaKuroki, Y., Sakuma, M., Taketani, Y., Takeda, E., 2015. Flaxseed oil intake reduces serum small dense low-density lipoprotein concentrations in Japanese men: a randomized, double blind, crossover study. Nutr. J., 14 (1), 39.

Khan, S.A., Makki, A., 2017. Dietary changes with omega-3 fatty acids improves the blood lipid profile of Wistar Albino rats with hypercholesterolaemia. Int. J. Med. Res. Health Sci., 6, 34-40.

Kris-Etherton, P.M., Harris, W.S., Appel, L.J., 2002. Fish consumption, fish oil, omega-3 fatty acids, and cardiovascular disease. Circulation, 106, 2747-2757.

Ling, E.F., 1963. A Text Book of Dairy Chemistry. Practical, (3 ${ }^{\text {rd }}$ Ed.), Chapman and Hall Ltd., London, pp. 58-65.

Lucas, E.A., Lightfoot, S.A., Hammond, L.J., Devareddy, L., Khalil, D.A., Daggy, B.P., Arjmandi, B.H., 2004. Flaxseed reduces plasma cholesterol and atherosclerotic lesion formation in ovariectomized Golden Syrian hamsters. Atherosclerosis, 173, 223-229.

Mancini, M., Parillo, M., 1991. Lipid intake and atherosclerosis. Ann. Nutr. Metabol., 35: (Suppl. 1), 103-108.

Metwally, M.M, El-shibiny, S., El-Dieb S.M., Asem, F.M., 1996. Effect of packaging materials on the keeping quality of processed cheese. Egypt. J. Dairy Sci. 24, 1-12.

Meyer, A. 1973. Processed Cheese Manufacture. $1^{\text {st }} \mathrm{Ed}$. Food Trade Press, London.

Moghadasian, M.H., 2008. Advances in dietary enrichment with n-3 fatty acids. Crit. Rev. Food Sci. Nutr., 48, 402-410.

Mohamed, A.G., Abbas, H.M., Bayoumi, H.M., Kassem, J.M., Enab, A.K., 2011. Processed cheese spreads fortified with oat. J. Am. Sci., 7, 631-637.

Mohamed, M.S., Afifi, A.A., 2011. Effect of some polyunsaturated fatty acids rich-oils on plasma lipid profiles using normal rats. J. Agric. Chem. Biotechnol., Mansoura Univ., 2, 49-59.

Morise, A., Sérougne, C., Gripois, D., Blouquit, M.F., Lutton, C., Hermier, D., 2004. Effects of dietary alpha linolenic acid on cholesterol metabolism in male and female hamsters of the LPN strain. J. Nutr. Biochem., 15: 51-61.
Morise, A., Mourot, J., Riottot, M., Weill, P., Fénart, E., Hermier, D., 2005. Dose effect of alpha-linolenic acid on lipid metabolism in the hamster. Reprod. Nutr. Dev., 45, 405-418.

Nishina, P.M., Lowe, S., Verstuyft, J., Naggert, J.K., Kuypers, F.A., Paigen, B., 1993. Effects of dietary fats from animal and plant sources on dietinduced fatty streak lesions in C57BL/6 J mice. J. Lipid Res., 34, 1413-1422.

Nordov, A., Goodnight, S.H., 1990. Dietary lipids and thrombosis. Relationships to atherosclerosis. Arterioscler Thromb. Vasc. Biol., 10, 149-163.

Olson, N.F., Price, W.V., 1958. A melting test for pasteurized processed cheese spread. J. Dairy Sci., 41, 999-1000.

Riediger, N.D., Othman, R., Fitz, E., Pierce, G.N., Suh, M., Moghadasian, M.H., 2008. Low n-6:n-3 fatty acid ratio, with fish- or flaxseed oil, in a high fat diet improves plasma lipids and beneficially alters tissue fatty acid composition in mice. Eur. J. Nutr., 47, 153-160.

Robbins, S.L., Cortan, R.S., 1981. The Pathological Basis of Disease. Philadelphia. PA: W.B. Saunders.

Saad, S.A., El-Mahdi, L.D., Awad R.A., Hassan, Z.M.R., 2016. Impact of different food protein sources in processed cheese sauces manufacture. Int. J. Dairy Sci., 11, 52-60.

SAS, 2001. Statistical Analysis System. SAS User's Guide: Statistics. SAS Institute Inc., Cary, NC, USA.

Savello, P.A., Ernstrom, C.A., Kalab, M. 1989. Microstructure and meltability of model process cheese made with rennet and acid casein. J. Dairy Sci., 72, 1-11.

Shalaby, S.M., Yasin, N.M.N., 2013. Quality characteristics of croissant stuffed with imitation processed cheese containing microalgae Chlorella vulgaris biomass. World J. Dairy Food Sci. 8, 58-66.

Shamsia, S., Yacoub, S., Ziena, H., Safwat, N., 2011. Chemical, microbiological, rheological and organoleptic properties of processed cheese blocks made by using mixture of soybean lecithin and commercial emulsifying salt. J. Agric. Environ. Sci., 10, 1-26.

Solowiej, B., 2007. Effect of $\mathrm{pH}$ on rheological properties and meltability of processed cheese analogs with whey products. Polish J. Food Nutr. Sci., 57, 125-128.

Soltan, S.S.A.M., 2012. The effects of varieties sources of omega-3 fatty acids on diabetes in rats. Food Nutr. Sci., 3, 1404-1412.

Strolien, H.H., Kriketos, A.D., Calvert, G.D., Baur, L.A., Jenkins, A.B., 2007. Fatty acids, triglycerides and syndromes of insulin resistance. Prostaglandins and plasma lipid and 
lipoprotein metabolism in human: a critical review. Diabetes Care, 30, 1012-1024.

Thomas, M.A. 1973. The use of a hard milk fat fraction in processed cheese. Aust. J. Dairy Technol., 28, 77-80.

Tietz NW., 1986. Methods of determination of ascorbic acid. In Text Book of Clinical Biochemistry. Tietz NW, Ed. Philadelphia, Pennsylvania, Elsevier Saunders, pp. 960-962

Tou, J.C., Altman, S.N., Gigliotti, J.C., Benedito, V.A., Cordonier, E.L., 2011. Different sources of omega-3 polyunsaturated fatty acids affects apparent digestibility, tissue deposition, and tissue oxidative stability in growing female rats. Lipids Health Dis., 10, 179.

Tzang, B.S., Yang, S.F., Fu, S.G., Yang, H.C., Sun, H.L., Chen, Y.C., 2009. Effects of dietary flaxseed oil on cholesterol metabolism of hamsters. Food Chem., 114, 1450-1455.
Vijaimohan, K., Jainu, M., Sabitha, K.E., Subramaniyam, S., Anandhan, C., Devi, C.S., 2006. Beneficial effects of alpha linolenic acid rich flaxseed oil on growth performance and hepatic cholesterol metabolism in high fat diet fed rats. Life Sci., 79, 448-454.

Whitby, L.G., Percy-Robb, I.W., Smith, A.F., 1984 Lecture notes on clinical chemistery, $3^{\text {rd }}$ Ed., Blackwell Scientific Publications, Oxford London, Boston, Edinburgh, Pale ALTO and Melbourne, pp. 256.

Zilva, J.F., Panmall, P.R., Mayne, P.D., 1991. Clinical Chemistry in Diagnosis and Treatment, England Clays Ltd. St. Ives Plc., England, pp. 233.

Zommara, M.A., El-Baz, A.M., Rashed, M.A., Mansour, A.A., 2006. Health promoting effects of mixed Zabady and Bifidobacteria fermented milks fed to rats. Egypt. J. Dairy Sci. 34, 47-57. 


\section{دراسات كميائية وييولوجية على الجبن المعامل القابل للفرد المصنع باستخدام زيت بذرة الكتان كبديل للزبد سمير عكلثة احمد شلبي '، رذق عزب عواد '، منصور عبده على '، محد راشد محمد راشد '، 1 قسم الالبان، كلية الزراعة بالقاهرة، جامعة الوزهر، القاهرة، مصر r قسم علوم وتكنولوجيا المذذية، كلية الزراعة، جامعة عين شمس، القاهة، مصر}

Mohamedrashed_5@azhar.edu.eg: البريد الإيكتروني للباحث الرئيسي: * الملخص العربي

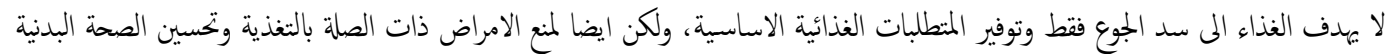

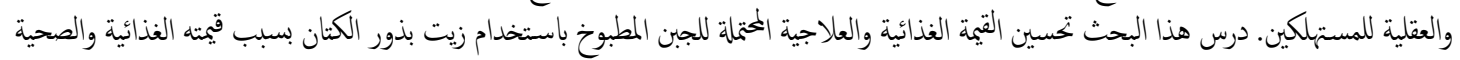

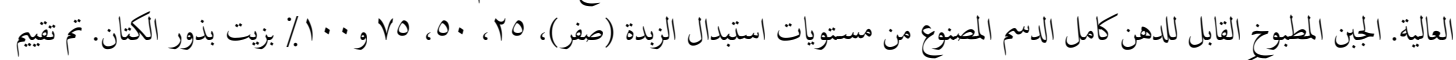

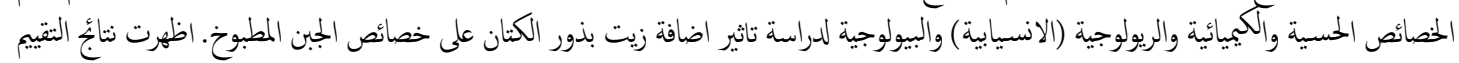

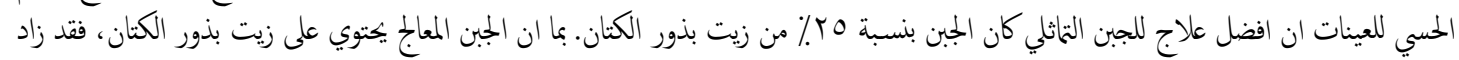

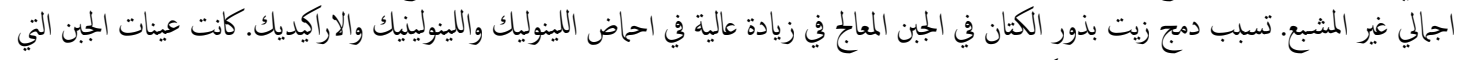

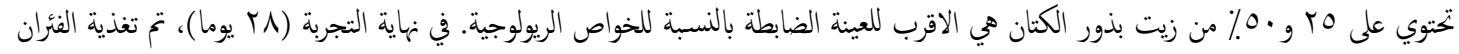

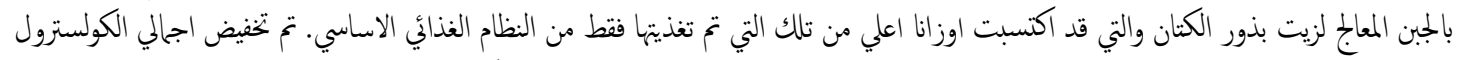

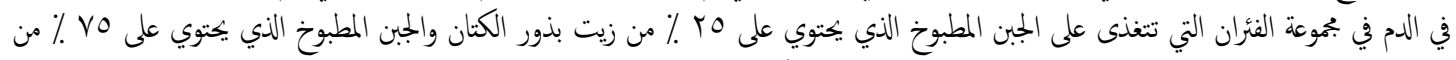

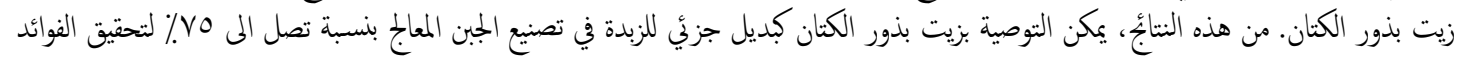
الصحية المقترحة مع القبول الحسي الجبد والخصائص الريولوجية المعقولة.

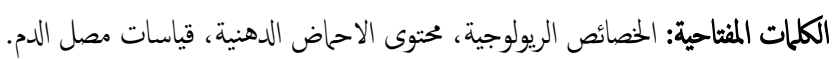

